\title{
Dark tourism: motivations and visit intentions of tourists
}

Dark tourism: motivations and intentions

\author{
Heather Lewis \\ Troy University, Troy, Alabama, USA \\ Thomas Schrier \\ Iowa State University, Ames, Iowa, USA, and \\ Shuangyu Xu \\ University of Missouri, Columbia, Missouri, USA
}

Received 11 January 2021 Revised 13 January 2021 Accepted 13 January 2021

\begin{abstract}
Purpose - The overall purpose of this study is to utilize the Theory of Planned Behavior (TPB) in combination with four dark tourism constructs (dark experience, engaging entertainment, unique learning experience, and casual interest) to gain a better understanding of behaviors and intentions of tourists who have visited or plan to visit a dark tourism location.

Design/methodology/approach - A total of 1,068 useable questionnaires was collected via Qualtrics Panels for analysis purposes. Confirmatory Factor Analysis (CFA) was used to verify satisfactory reliability and validity regarding the measurement of model fit. With adequate model fit, structural equation modeling was employed to determine positive and negative relationships between TPB and dark tourism constructs. In all, 11 hypotheses statements were tested within this study.

Findings - Results of this study indicate that tourists are curious, interested, and intrigued by dark experiences with paranormal activity, resulting in travel choices made for themselves based on personal beliefs and preferences, with minimal outside influence from others. It was determined that dark experience was the most influential of the dark tourism constructs tested in relationship to attitudes and subjective norm.

Research limitations/implications - The data collected for this study were collected using Qualtrics Panels with self-reporting participants. The actual destination visited by survey participants was also not factored into the results of this research study.

Originality/value - This study provides a new theoretical research model that merges TPB and dark tourism constructs and established that there is a relationship between TPB constructs and dark tourism.
\end{abstract}

Keywords Dark tourism, Thanatourism, Motivations, Intentions, Theory of planned behaviour

Paper type Research paper

\section{Introduction}

Dark tourism is defined as the act of tourists traveling to sites of death, tragedy, and suffering (Foley and Lennon, 1996). This past decade marks a significant growth of dark tourism with increasing number of dark tourists (Lennon and Foley, 2000; Martini and Buda, 2018). More than 2.1 million tourists visited Auschwitz Memorial in 2018 (visitor numbers, 2019), and 3.2 million tourists visited the Ground Zero 9/11 Memorial annually (a year in review, 2017). Despite of the increasing popularity, there is still limited understanding of dark tourism as a multi-faceted phenomenon (Biran et al., 2011). Some research has looked into the motivations and experience of dark tourists (Poria et al., 2004; Poria et al., 2006). However, most were based on conceptual frameworks and arguments with little empirical data, even less have examined tourist visit intentions to dark tourism sites (Zhang et al., 2016), let alone the association between dark tourists' motivations and visit intentions. Many scholars suggested the

(C) Heather Lewis, Thomas Schrier and Shuangyu Xu. Published in International Hospitality Review. Published by Emerald Publishing Limited. This article is published under the Creative Commons Attribution (CC BY 4.0) licence. Anyone may reproduce, distribute, translate and create derivative works of this article (for both commercial and non-commercial purposes), subject to full attribution to the original publication and authors. The full terms of this licence may be seen at http://creativecommons. org/licences/by/4.0/legalcode

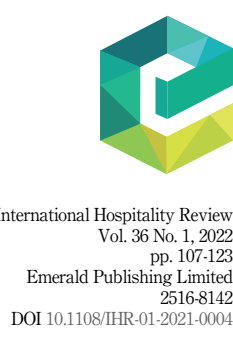


IHR

36,1

108

pressing needs for empirical research into dark tourism from tourist perspectives to understand their motivations and experiences (Seaton and Lennon, 2004; Sharpley and Stone, 2009; Zhang et al., 2016). Of the limited empirical dark tourism studies, most were case studies with historical battlefields and concentration camps being the hot spots (Le and Pearce, 2011; Lennon and Foley, 1999; Miles, 2002). Still, a comprehensive understanding of dark tourists' motivations and their intentions to visit is lacking.

As such, this study was conducted to understand both the motivations and visit intentions of tourists to dark tourism destinations. Theory of Planned Behavior (TPB) constructs (attitudes, subjective norm, perceived behavioral control) and the four dark tourism dimensions (i.e. dark experience, engaging entertainment, unique learning experience, and casual interest) were utilized to address the following objectives: (1) examine the motivations of dark tourists; (2) investigate the intentions of the dark tourists to visit a dark tourism destination in the next 12 months; and (3) explore the association between the motivations and visit intentions of dark tourists. The dark tourism dimensions utilized for this study were adapted supported by previous dark tourism studies (Biran et al., 2014; Bissell, 2009; Lam and Hsu, 2006; Molle and Bader, 2014). While many studies have utilized TPB in the past, this study will utilize the TPB to focus attention on why travelers are motivated to visit dark tourism locations specifically.

\section{Literature review}

Travels associated with death dates back for centuries (Dale and Robinson, 2011). Early examples of dark tourism include Roman gladiator games, guided tours to watch hangings in England, and pilgrimages to medieval executions (Stone, 2006). Even today, many tourists are fascinated with and thus visited sites of death and tragedy such as the John F. Kennedy's death site in Dallas, Texas, and the Ground Zero 9/11 Memorial in New York (Foley and Lennon, 1996; Strange and Kempa, 2003). Abandoned prisons and sites of punishment and incarcerations are also popular attractions among dark tourists (e.g., Pentridge in Melbourne, Australia; Foley and Lennon, 1996). However, the term dark tourism did not get introduced to the research community until 1996 which ignited many later research efforts on this topic (Light, 2017).

\section{Dark tourism}

Dark tourism is defined as the act of tourists traveling to sites of death, tragedy, and suffering (Foley and Lennon, 1996). Many scholars also came up with other terms and labels to describe such phenomenon including thanatourism (Seaton, 1996), disaster tourism (Rojek, 1993), black spot tourism (Rojek, 1993), morbid tourism (Blom, 2000) and even phoenix tourism (Powell et al., 2018). Mowatt and Chancellor (2011) suggested that despite of different names, at the heart of the concept is travel to places of death that are often linked to violence (Robb, 2009). Many researchers use the term dark tourism and thanatourism interchangeably, while more tend to use dark tourism as an umbrella term for any form of tourism that is somehow related to death, suffering, atrocity, tragedy or crime (Light, 2017). Given the standard use of the term dark tourism in the practice and scholarship of tourism, such a term will be used throughout this manuscript.

Dark tourism research in this past two decades mainly covers six themes including the discussion on definition, concepts, and typologies; the associated ethical issues; the political and ideological dimensions; the nature of demand for dark tourism locations; site management; and the methods used for research (Light, 2017). The area of terminology and definitions undoubtedly dominates in the dark tourism literature (Zhang et al., 2016). While in the area of exploring the nature of demand for dark tourism locations, the relatively 
limited research concentrated in four aspects - both the motivations and experiences of dark tourists, the relationship between visiting and sense of identity, and new approaches to theorizing the consumption of dark tourism (Light, 2017).

Research addressing dark tourists' motivations were relatively slow. Many early studies simply postulate and propose tourists' motivations to visit dark tourism sites, with a lack of empirical research to support (Light, 2017). As such, many studies in the past decade examined dark tourists' motivations through different case studies, with concentration camps or historical battlefields being the hot spots (Lennon and Foley, 1999; Miles, 2002). Research reveals that tourists visit dark tourism destinations for a wide variety of reasons, such as curiosity (Biran et al., 2014; Isaac and Cakmak, 2014), desire for education and learning about what happened at the site (Kamber et al., 2016; Yan et al., 2016), interest in history or death (Yankholmes and McKercher, 2015; Raine, 2013), connecting with one's personal or family heritage (Mowatt and Chancellor, 2011; Le and Pearce, 2011). Drawing from literature, four common themes (i.e. dark experience, engaging entertainment, unique learning experience, casual interest) emerged, served as the foundational pillars for this study, and were discussed below.

\section{The motivation construct}

Dark Experience. Raine's (2013) dark tourist spectrum study of tourists visiting burial grounds and graveyards concluded that mourners and pilgrims had personal and spiritual connections to the different sites being studied. Mourners visited specific gravesites and usually would perform meditations for the dead. Pilgrims had a personal connection to specific burial sites in some way, whether it is a religious connection to the individual or they served as a personal hero (Raine, 2013). Death rites are often performed as a ritual not necessarily to mark the passing of the deceased but rather to heal the wounds of families, communities, societies, and/or nations by the deceased's passing (Bowman and Pezzullo, 2009).

Additionally, Raine's (2013) study discovered another subset of tourists- the morbidly curious and thrill seekers. Those classified as morbidly curious or thrill seekers were visiting burial sites to confront and experience death. Whether a mourner or pilgrim or the morbidly curious thrill seeker, the tourists had a strong connection to the dead they were there to visit which could categorize them as seeking a dark experience.

To take dark tourism to the extreme, Miller and Gonzalez (2013) completed a study on death tourism. Death tourism occurs when individuals travel to a location to end their lives, often through a means of assisted medical suicide. It was determined that this is still a taboo topic for some countries where it is not legalized, however it is gaining more publicity. It was determined that death tourism is typically the result of one of four reasons; the primary reason death tourism is planned is because of assisted suicide being illegal in the traveler's home country (Miller and Gonzalez, 2013). While death tourism does not directly apply to this particular study, it is an offspring of dark tourism and is a tourist activity that is related to dark experience.

Dark experience closely relates to acts of death and dying, as well as fascination with the abnormal, bizarre, and emotional experiences that come with visiting a dark tourism destination (Bissell, 2009). Previous research has shown that individuals have a morbidly curious interest in death and the act of witnessing death (Raine, 2013). This dimension was developed specifically to test statements related to death, fascination with abnormal and/or bizarre events and locations, as well as emotional experiences related to death and dying. Based on previous research, the following hypotheses statements were created:

H1. Dark Experience will have a positive relationship with Attitudes
Dark tourism: motivations and intentions 
IHR

36,1

\section{H2. Dark Experience will have a positive relationship with Subjective Norm}

Engaging Entertainment. Tourists may visit dark tourism destinations to see the reality behind the media images or to gain emotional connections to celebrities. Often, tourists have emotional connections to the locations in which they are traveling. For example, tours of Elvis' home, Graceland, or the accurate reenactment of James Dean's funeral procession offer visitors an experience different to everyday life and has been systematized (Foley and Lennon, 1996). It has been found that when tourists perceive a site to be part of their own heritage, they will show greater interest in learning, feeling emotional involvement, and being connected to their personal heritage (Poria et al., 2006). Some tourists visit dark tourism destinations especially those they have a personal heritage connection to (i.e. Auschwitz, Ground Zero, war battlefields), just to experience the personal and emotional connections (Poria et al., 2006). As a result of previous research, the following hypotheses statements were made regarding Engaging Entertainment:

\section{H3. Engaging Entertainment will have a positive relationship with Attitudes}

H4. Engaging Entertainment will have a positive relationship with Subjective Norm

Unique learning experience. Raine (2013) studied dark tourists to burial sites and graveyards and found that their primary motivations were to explore, make discoveries, and for education. These tourists only visited for a pleasurable experience, and thus are usually emotionally detached and might not engage with the site as a burial ground (Raine, 2013). In some cases, tourists may be visiting the destination for purposes other than dark tourism interest (e.g., photography, education). Farmaki (2013) investigated the motivations of tourists to dark heritage sites in Cyprus and found that even though the concept of death was incorporated to enhance tourists' experience, the dark tourism sites were primarily for educational and memorial purposes and thus become places of commemoration, admiration, and learning (Farmaki, 2013). In connection with the Unique Learning Experience construct, the following hypotheses statements were concluded:

H5. Unique Learning Experience will have a positive relationship with Attitudes

H6. Unique Learning Experience will have a positive relationship with Subjective Norm

Casual interest. Raine (2013) classified certain tourists (i.e., sightseers, retreaters, and passive recreationalists) as "incidental" given the nature of their visits was often unplanned. Instead of visiting to experience events related to death and burials, these tourists visited either because of their general interests in the area or to escape from stresses of everyday life (Raine, 2013). Tourists could encounter dark tourism unknowingly as they are just wanting something to do while on vacation and happen upon a dark tourism destination or activity. As a result of previous research, the following hypotheses statements were created to test casual interest:

H7. Casual Interest will have a positive relationship with Attitudes

H8. Casual Interest will have a positive relationship with Subjective Norm

\section{The Theory of Planned Behavior (TPB)}

Behavioral intention, defined as an individual's anticipated or planned future behavior (Swan, 1981), has been suggested as a central factor that correlates strongly with observed behavior (Baloglu, 2000). Many believed that intentions serve as an immediate antecedent to actual behavior (Fishbein and Ajzen, 1975; Konu and Laukkanen, 2010). Fishbein and Ajzen developed the Theory of planned behavior (TPB) base on three constructs: attitude, subjective norm and perceived behavioral control. The Theory of Planned Behavior (TPB) 
has been widely used in tourism research (Ajzen and Driver, 1992; Han et al., 2010; Han and Kim, 2010; Lam and Hsu, 2004, 2006). TPB suggests that individuals are more likely to engage in behaviors that are believed to be achievable (Armitage and Conner, 2001). Ajzen (1991) suggested that attitude, subjective norm, and perceived behavioral control are important to predict intention. Perceived behavioral control is what influences the tourists' intentions and their perception of their ability to perform a specific behavior.

Lam and Hsu (2004) utilized the TPB to examine motivations of travelers from mainland China to Hong Kong and found that attitude, perceived behavioral control, and past behaviors were directly related to travel intentions. In another study examining the visit intentions of Taiwanese travelers to Hong Kong, Lam and Hsu (2006) found that a positive association between visit frequency and re-visit intention.

Cheng et al. (2006) used the TPB to examine the negative word-of-mouth communication on visit intentions of Chinese consumers to high-class Chinese restaurants. It was determined from their study that the TPB constructs were positively impacted by negative word-ofmouth indicating that the TPB effectively measured consumer communication intention. Similarly, Han and Kim (2010) modified the TPB in the investigation of customers' intention to revisit environmentally friendly hotels and found that past behavior was a significant predictor of intention-the more customers stay at a green hotel, the more likely they intend to revisit. It can be concluded from previous research efforts that the TPB can be utilized to effectively measure behavioral intentions of tourists successfully.

\section{Motivation and intentions}

Understanding motivations is the starting point of understanding tourist behaviors (Crompton, 1979; Kim et al., 2011). Tourist motivations (e.g., excitement, relaxation, curiosity) are found to have a direct positive effect on their behavioral intentions (Yoon and Uysal, 2005). Many suggested that additional constructs (e.g., tourist motivations, satisfactory prior experience) can enhance the predictive power of TPB (Conner and Abraham, 2001; Alegre and Cladera, 2009). Several studies have shown that motivations have a positive effect to behavioral intention or affects intention to visit (Baloglu, 2000; Yoon and Uysal, 2005) or to use a certain product/service (e.g., Alegre and Cladera, 2009; Vazquez and Xu, 2009). For purposes of this study, the Theory of Planned Behavior (TPB) is utilized to serve as a guide to determine behavioral intentions. Concluded from previous research, the following hypotheses statements have been developed to test the relationships of the Theory of Planned Behavior:

H9. Attitudes will have a positive relationship with Intention

H10. Subjective Norm will have a negative relationship with Intention

H11. Perceived Behavioral Control will have a positive relationship with Intention

\section{Methodology}

Survey instrument

A survey questionnaire was developed to collect information on the socio-demographic background, motivation construct, and planned behavior construct from tourists. Sociodemographic data queried were age in years (continuous), gender (3 categories, male, female and prefer not to answer), level of education (9 categories, from less than high school degree to doctoral degree), marital status (5 categories, from single to widow/widower), personal annual income (12 categories, from less than $\$ 20,000$ to more than $\$ 200,000$ ). Tourists' home residence state and country were also collected.

A dark tourism motivation construct was developed based on previous studies (Biran et al., 2014; Bissell, 2009; Lam and Hsu, 2006; Molle and Bader, 2014), and used to query previous
Dark tourism: motivations and intentions 
IHR

36,1

\section{2}

visit and potential visit separately using a five-point Likert scale (" 1 = extremely unimportant"; " $5=$ extremely important"). This motivation construct consists of 33 item statements from four dimensions (Table 1) which include engaging entertainment, dark experience, unique learning experience, and casual interest. Dark experience consisted of nine statements, related to death, fascination with abnormal and/or bizarre events and

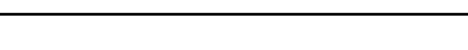

\begin{tabular}{cccc}
$\begin{array}{c}\text { Dark } \\
\text { experience }\end{array}$ & $\begin{array}{c}\text { Engaging } \\
\text { entertainment }\end{array}$ & $\begin{array}{c}\text { Unique learning } \\
\text { experience }\end{array}$ & $\begin{array}{l}\text { Casual } \\
\text { interest }\end{array}$ \\
\hline 0.86 & & & \\
0.81 & & &
\end{tabular}

To visit well-recognized locations that

are known to be home to paranormal activity

To experience paranormal activity as

0.80

seen on main-stream media

Well-known for paranormal activity

To satisfy my fascination of abnormal $\quad 0.60$

and bizarre events

To seek out stories related to the DT $\quad 0.55$

location

To satisfy personal curiosity about how $\quad 0.51$

the victims died

To witness the act of death and dying $\quad 0.48$

To reconnect with individual(s) that $\quad 0.48$

were somehow associated to the DT

location

To see the wreckage/debris of the DT

location

To be physically refreshed

To be emotionally refreshed

To have a hobby

To meet people with similar interests

To change pace and get away from

routine

To see the improvement/changes of the

DT location

To travel

To have some entertainment

Has been featured on television shows

To try something "out of the ordinary"

To try something new

To experience place(s) many people

have not been to or wish to visit

To increase knowledge

To visit historical/cultural sites

Originality of facilities

Well-known for historical heritage

60

0.43

To experience a part of my own

heritage

Special tour promotions

Value of tours

Service quality

Personal safety

Table 1.

To have an enjoyable time with family 
destinations, and emotional experiences with a connection to death (e.g., "to travel", "to have some entertainment"). Engaging entertainment was measured using ten statements that inquire about the personal or emotional connection to the destination they have visited or wish to visit in the future (e.g., "to witness the act of death and dying", "to experience paranormal activity"). Unique learning experience focused on learning about the history of the destination being visited or trying something that is different and out of the ordinary (eight items, e.g., "to try something new", "to increase knowledge"). Casual interest focuses on individuals who want to visit a dark tourism destination for the entertainment value but want to have a relaxing time while doing so (six items, "special tour promotions", "natural scenery").

The planned behavior construct queried on four dimensions (i.e., attitudes, subjective norms, perceived behavioral control, and behavioral intentions) associated with visiting dark tourism destinations, with a total of 16 item statements (Table 2). Five item statements were used to measure dark tourists' attitudes (e.g., "visiting a dark tourism destination is enjoyable", "visiting a dark tourism destination is pleasant") and behavioral intentions (e.g., "I will visit a dark tourism destination in the next 12 months", "I would revisit the most recent dark tourism destination I visited again in the future") respectively, using a five-point Likert scale ("1 = Strongly disagree"; "5 = Strongly agree"). Dark tourists' perceived behavioral control was measured by three item statements (e.g., "I am in control of whether or not I visit a dark tourism destination", "If wanted, I could easily afford to visit a dark tourism destination"), using the same five-point Likert scale (" 1 = Strongly disagree"; " 5 = Strongly agree"). For subjective norms dimension, each of the three item statements was measured by a different five-point Likert scale. The statement that "most people I know would choose a dark tourism destination for vacation purposes" uses the scale in which " 1 = strongly disagree", " 5 = strongly agree". One item statement asks individuals to rate on whether "people who are important to me think I choose a dark tourism destination to visit" " 1 = definitely

\begin{tabular}{|c|c|c|c|c|}
\hline Construct & Parcel & Variable & $\begin{array}{l}\text { Factor } \\
\text { loading }\end{array}$ & \\
\hline \multirow[t]{5}{*}{ Attitude } & 1 & (ATT_4) Fun & 0.79 & \\
\hline & 2 & (ATT_1) Enjoyable & 0.79 & \\
\hline & & (ATT_5) Positive & 0.57 & \\
\hline & 3 & (ATT_3) Exciting & 0.71 & \\
\hline & & (ATT_2) Pleasant & 0.67 & \\
\hline \multirow{4}{*}{ Behavioral Intention } & 1 & (BI_1) I will visit a DT location in the next 12 mos & 0.69 & \\
\hline & 2 & $\begin{array}{l}\text { (BI_4) I would recommend visiting the most recent DT } \\
\text { location I visited to a friend/family member }\end{array}$ & 0.65 & \\
\hline & & $\begin{array}{l}\text { (BI_3) I would revisit the most recent DT location I visited } \\
\text { again in the future }\end{array}$ & 0.54 & \\
\hline & 3 & $\begin{array}{l}\text { (BI_2) I want to visit a DT location in the next } 12 \mathrm{mos} \\
\text { (BI_5) I would recommend visiting any DT location to a } \\
\text { friend/family member }\end{array}$ & $\begin{array}{l}0.62 \\
0.58\end{array}$ & \\
\hline \multirow[t]{3}{*}{ Subjective Norms } & 1 & $\begin{array}{l}\text { (SN_2) People who are important to me think I should/should } \\
\text { not choose a DT location to visit }\end{array}$ & 0.84 & \\
\hline & 2 & $\begin{array}{l}\text { (SN_3) People who are important to me would approve/ } \\
\text { disapprove of my visit to a DT location }\end{array}$ & 0.77 & \\
\hline & 3 & $\begin{array}{l}\text { (SN_1) Most people I know would choose a DT location for } \\
\text { vacation purposes }\end{array}$ & 0.52 & \\
\hline Perceived Behavioral & 1 & (PBC_1) I am in control of whether or not I visit a DT location & 0.52 & Table 2. \\
\hline \multirow[t]{2}{*}{ Control } & 2 & $\begin{array}{l}\text { (PBC_3) There are DT location(s) within reasonable driving } \\
\text { distance from my home }\end{array}$ & 0.46 & $\begin{array}{l}\text { Partial disaggregation } \\
\text { parcel groupings of }\end{array}$ \\
\hline & 3 & (PBC_2) If I wanted, I could easily afford to visit a DT location & 0.45 & TPB variables \\
\hline
\end{tabular}


IHR

36,1

should not", " 5 = definitely should"). Another statement asks individuals to rate whether "people who are important to me would __ of my visit to a dark tourism destination" " 1 = definitely disapprove", " 5 = definitely approve").

\section{Sampling and procedure}

To increase the reliability and validity of the survey, a pilot study was conducted. A small group of industry professionals from all over the country currently working at dark tourism destinations and other academic researchers were invited to critique the initial draft of the survey. Forty-one individuals took the survey instrument and provided feedback (e.g., some wording issues). After revisions from the pilot study were completed, the survey was launched, and data was collected.

Qualtrics, a web-based survey software company with access to an electronic database of survey candidates, was used to administer this questionnaire to participants. A total of 44,270 invitations were randomly sent to Qualtrics panel participants requesting participation in this study. Qualification of participants was completed by requesting all survey recipients answer the following questions: (1) Have you visited a dark tourism location within the past 24 months? and (2) Do you plan to visit a dark tourism location within the next 12 months? A statement was provided to all participants explaining what consisted of a dark tourism location to ensure participants were not taking the survey based on experiences of activities like haunted houses or haunted hayrides. Only 3,907 individuals were eligible to complete the survey, and a total of 1,068 participants did complete the survey, which yields a response rate of $27.3 \%$. Altogether 651 out of 1,068 individuals had previously visited a dark tourism destination within the last 24 months while the remaining 417 individuals plan to visit a dark tourism destination within the next 12 months.

\section{Analysis}

Data analysis included descriptive statistics, reliability tests, confirmatory factor analysis (CFA), and structural equation modeling (SEM). Descriptive statistics were used to outline respondents' characteristics (e.g., demographic composition). CFA was utilized to evaluate the measurement model, demonstrate adequate model fit, and ensure satisfactory levels of reliability and validity of underlying variables and their respective factors. Factor loadings greater than 0.70 indicated that the constructs are appropriately represented and considered acceptable (Hair et al., 2010). Cronbach's alphas were computed to test the internal reliability of items comprising each dimension of the dark tourism motivation construct (dark experience, engaging entertainment, unique learning experience, casual interest) and the planned behavior construct (attitudes, subjective norm, perceived behavioral control), respectively. A cutoff value of 0.7 was utilized to determine "good" reliability (Peterson, 1994, p. 381).

To confirm measurement model validity, the chi-squared $\left(x^{2}\right)$ statistic, Root-Mean-SquareError of Approximation (RMSEA), Comparative Fit Index (CFI), and the Standardized Root Mean Square Residual (SRMR) values were reviewed. Cutoff criteria used to determine "good fit" were RMSEA score $<0.08$ (Byrne, 1998), CFI scores $>0.90$ (Kline, 2005), SRMR $<0.08$ to indicate a good fit (Hu and Bentler, 1999).

\section{Results}

Overwhelmingly, many tourists who had either visited a dark tourism location or plan to visit a dark tourism destination were female $(65.4 \%)$. Additionally, the majority of participants were $25-34$ years of age (44.2\%) with the next largest age groups being $35-44$ years $(21 \%)$ and $18-24$ years $(20.9 \%)$. Most had either a 4 -years Bachelor's degree from college $(30.5 \%)$ or at least some college education but did not finish their degree (25.3\%). $54.5 \%$ of the survey 
participants were married and $37.6 \%$ were single. As for income, the largest percentage $(19.5 \%)$ had an individual annual income ranging from $\$ 20,001-\$ 40,000$. A full table of demographic characteristics of the participants can be seen in Table 3 .

\section{Partial disaggregation of measurement model}

SEM was utilized to investigate the relationships among dark tourism construct, the planned behavior construct and behavioral intentions. Like the CFA testing, the SEM also uses the chi-squared $\left(x^{2}\right)$, RMSEA, SRMR, and CFI to determine overall model fit and relationships for this study. After further testing for convergent and discriminant validity, it was determined that all constructs met the composite reliability 0.70 or greater standard regarding the 3parcel hypothesized model (Table 4) (Hair et al., 2010).

There are several ways to parcel variables into groupings. For purposes of this study, the variables were parceled using the item-to-construct method since the SEM model was large in size and the goal was to have parcels balanced in terms of difficulty and discrimination (Little et al., 2002). To develop the parcels, standardized regression weights were evaluated, and the

\begin{tabular}{|c|c|c|c|}
\hline \multicolumn{2}{|c|}{ Demographic characteristics } & \multirow{2}{*}{$\frac{\text { Frequency }}{368}$} & \multirow{2}{*}{$\frac{\text { Percentage }}{34.5}$} \\
\hline Gender & Male & & \\
\hline & Female & 698 & 65.4 \\
\hline & Prefer not to answer & 2 & 0.2 \\
\hline \multirow[t]{7}{*}{ Age } & 18-24 years & 223 & 20.9 \\
\hline & $25-34$ years & 472 & 44.2 \\
\hline & $35-44$ years & 224 & 21.0 \\
\hline & 45-54 years & 78 & 7.3 \\
\hline & $55-64$ years & 43 & 4.0 \\
\hline & $65-74$ years & 26 & 2.4 \\
\hline & Over 75 years & 2 & 0.2 \\
\hline \multirow{9}{*}{ Level of Education } & Less than high school degree & 9 & 0.8 \\
\hline & High school graduate (diploma or GED equivalent) & 116 & 10.9 \\
\hline & Some college but no degree & 270 & 25.3 \\
\hline & Associate degree in college (2-years) & 98 & 9.2 \\
\hline & Bachelor's degree in college (4-years) & 326 & 30.5 \\
\hline & Master's degree & 155 & 14.5 \\
\hline & Doctoral degree & 35 & 3.3 \\
\hline & Professional degree (JD, MD) & 56 & 5.2 \\
\hline & I prefer not to say & 3 & 0.3 \\
\hline \multirow[t]{5}{*}{ Marital Status } & Single & 402 & 37.6 \\
\hline & Married & 582 & 54.5 \\
\hline & Divorced/Separated & 72 & 6.7 \\
\hline & Widow/Widower & 8 & 0.7 \\
\hline & I prefer not to say & 4 & 0.4 \\
\hline \multirow[t]{12}{*}{ Annual Income } & Less than $\$ 20,000$ & 177 & 16.6 \\
\hline & $\$ 20,001$ to $\$ 40,000$ & 208 & 19.5 \\
\hline & $\$ 40,001$ to $\$ 60,000$ & 172 & 16.1 \\
\hline & $\$ 60,001$ to $\$ 80,000$ & 153 & 14.3 \\
\hline & $\$ 80,001$ to $\$ 100,000$ & 143 & 13.4 \\
\hline & $\$ 100,001$ to $\$ 120,000$ & 55 & 5.1 \\
\hline & $\$ 120,001$ to $\$ 140,000$ & 36 & 3.4 \\
\hline & $\$ 140,001$ to $\$ 160,000$ & 39 & 3.7 \\
\hline & $\$ 160,001$ to $\$ 180,000$ & 10 & 0.9 \\
\hline & $\$ 180,001$ to $\$ 200,000$ & 12 & 1.1 \\
\hline & More than $\$ 200,000$ & 20 & 1.9 \\
\hline & I prefer not to say & 43 & 4.0 \\
\hline
\end{tabular}

Dark tourism: motivations and intentions
Table 3.

Demographic characteristics of survey participants 
IHR

36,1

116

three highest scores served as anchors to each of the three parcels with the highest values associated to parcel 1 , next highest to parcel 2 , and then the next highest to parcel 3 . The remainder of variables were placed into the parcels continuing with the 4th highest value placed into the 3rd parcel and repeating the process in inverted order until all variables were assigned into parcels. Once the variables for each construct were placed into appropriate parcel groupings, averages of the questions associated to the new parceled variables were calculated prior to the CFA and SEM analysis. The attitude and behavioral intention constructs had five variable questions, while subjective norm and perceived behavioral control only had three questions. In those situations, one individual variable question served as the parcel item. Table 2 shows the variables and the parcels in which they were grouped.

Additionally, the average variance extracted was calculated and proved to be less than the composite reliability for each construct indicating convergent reliability of the constructs. The average variance extracted was greater than the 0.50 standard for Dark Experience, Engaging Entertainment, Unique Learning Experience, Attitude, and Subjective Norm constructs. Behavioral Intention (0.49) and Casual Interest (0.48) had values that were borderline acceptable regarding convergent validity. The only construct that did not meet the standards of convergent validity testing was Perceived Behavioral Control (0.23). When testing for divergent validity, all square-root of average variance extracted calculations were greater than the inter-construct correlations indicating divergent validity was present in this study. Partial disaggregation of the variables resulted in a much stronger overall model fit. The RMSEA value was 0.08 indicating a strong model fit and the CFI (0.891) value was acceptable indicating a good model fit. The SRMR value (0.06, Table 4$)$ also showed a strong model fit.

\section{Hypothesis testing}

Overall, most of the relationships between the dark tourism construct and the TPB constructs were significant. Results show that dark experience has a positive significant relationship with both attitudes (0.434) regarding tourists visiting a dark tourism destination and subjective norms (0.242, Table 5). Casual interest has a positive significant relationship with both attitudes (0.404) and subjective norm (0.330). Both engaging entertainment ( -0.080 ; $-0.217)$ and unique learning experience $(0.152 ;-0.247)$ are not significantly associated with neither attitudes nor subjective norms. Results show that both attitudes (0.396) and perceived behavioral control (0.716) have a significant positive relationship with behavioral intention.

SEM testing was completed on the data. In addition to the significant and insignificant relationships indicated by the SEM testing, to answer some of the specific research questions asked by this study one must review the distinct question factor loadings to get those answers. A full set of the factor loadings of survey questions asked regarding dark tourism and TPB constructs are in Table 1 . A visualization of all hypothesis testing results is in Table 5 as well as on Figure 1.

\begin{tabular}{lrrrrrr}
\hline Model & \multicolumn{1}{c}{ Df } & \multicolumn{1}{c}{$\chi^{2}$} & CFI & RMSEA & SRMR & 90\% CI \\
\hline 8-factor 3-parcel hypothesized model & 224 & 1560.20 & 0.89 & 0.08 & 0.06 & {$[0.071,0.078]$} \\
8-factor single-parcel hypothesized model & 1 & 318.10 & 0.89 & 0.55 & 0.13 & {$[0.496,0.596]$} \\
8-factor full hypothesized model & 1099 & 8283.79 & 0.69 & 0.08 & 0.09 & {$[0.077,0.080]$} \\
7-factor model (DE, EE combined) & 231 & 2141.38 & 0.84 & 0.09 & 0.06 & {$[0.085,0.091]$} \\
7-factor model (ULE, CI combined) & 237 & 1831.23 & 0.87 & 0.08 & 0.06 & {$[0.076,0.083]$} \\
6-factor model (DE, EE combined; ULE, CI & 237 & 2314.35 & 0.83 & 0.09 & 0.07 & {$[0.087,0.094]$} \\
combined) & & & & & & \\
5-factor model (all DT constructs combined) & 246 & 3076.99 & 0.77 & 0.10 & 0.08 & {$[0.101,0.107]$} \\
\hline
\end{tabular}

Table 4. 


\begin{tabular}{|c|c|c|c|c|c|}
\hline Hypothesis & Path & Estimate & Significant & Result & Jark tourism: \\
\hline H1 & $\mathrm{DE} \rightarrow$ Attitudes & 0.434 & $p<0.001$ & Supported & and intentions \\
\hline $\mathrm{H} 2$ & $\mathrm{DE} \rightarrow \mathrm{SN}$ & 0.242 & $p<0.001$ & Supported & \\
\hline $\mathrm{H} 3$ & $\mathrm{EE} \rightarrow$ Attitudes & -0.080 & N.S. & Not supported & \\
\hline $\mathrm{H} 4$ & $\mathrm{EE} \rightarrow \mathrm{SN}$ & 0.152 & N.S. & Not supported & \\
\hline H5 & ULE $\rightarrow$ Attitudes & -0.217 & N.S. & Not supported & \\
\hline $\mathrm{H} 6$ & $\mathrm{ULE} \rightarrow \mathrm{SN}$ & -0.247 & N.S. & Not supported & 117 \\
\hline $\mathrm{H} 7$ & $\mathrm{CI} \rightarrow$ Attitudes & 0.404 & $p<0.001$ & Supported & \\
\hline H8 & $\mathrm{CI} \rightarrow \mathrm{SN}$ & 0.330 & $p<0.01$ & Supported & Table 5. \\
\hline H9 & Attitudes $\rightarrow$ Intention & 0.396 & $p<0.001$ & Supported & Full-data set \\
\hline H10 & $\mathrm{SN} \rightarrow$ Intention & 0.058 & N.S. & Not supported & hypothesis testing \\
\hline H11 & $\mathrm{PBC} \rightarrow$ Intention & 0.716 & $p<0.001$ & Supported & results \\
\hline
\end{tabular}

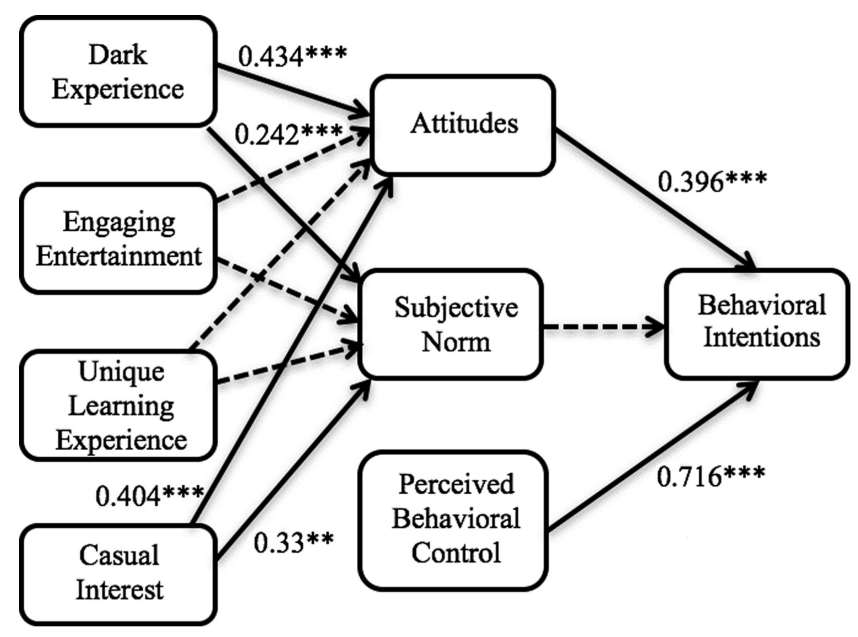

Note(s): $* * p<0.01, * * * p<0.001$; solid line: significant relationship; dashed line: non-significant relationship
Figure 1. Graphic representation of theoretical framework and hypothesis testing results

\section{Discussion}

It can be concluded from the findings of this research that dark experience has a positive relationship with attitudes regarding tourists visiting a dark tourism location, indicating that Hypothesis 1 was fully supported. Tourists seek specific characteristics when choosing to visit a dark tourism destination. Akin to findings from Bissell (2009), the reasons for visiting: I want to try something new and out of the ordinary as well as I am fascinated with abnormal and bizarre events were strong. Alone these two variables do not constitute wanting to experience dark tourism but suggest a curiosity about dark tourism and a desire for new experiences (Seaton and Lennon, 2004). Individuals answered favorably to all questions related to interest in experiencing paranormal activity. Although Sharpley (2005) suggested "fascination with death" as a potential motive for tourists to visit dark tourism destinations, questions specifically related to death (i.e., to witness the act of death and dying, to satisfy personal curiosity about how the victims died), reveal that fascination with death and dying was not a strong motivating factor for the tourists' who participated in this research study. The positive relationships of dark experience with attitudes (H1) and subjective norm (H2), respectively, 
IHR

36,1

118

implies that tourists are seeking experiences that satisfy curiosity or they are seeking interaction with the paranormal. Tourists seek a fun and enjoyable tourist experience by visiting dark tourism destinations, and do not feel pressured by societal norms of their friends and family, which may prevent them from visiting dark tourism destinations.

The engaging entertainment dimension regarding both attitude (H3) and subjective (H4) was not supported in this study, which is interesting considering the questions in this dimension were developed to determine the importance of the tourists connecting with the information presented at the destination while still having an enjoyable experience.

Like Raine (2013), this study considered the unique learning experience dimension to include individuals who are hobbyists and are typically visiting these destinations solely for educational purposes and to not engage with the destination as a dark tourism site. To present an alternative consideration to the construct of unique learning experience, Seaton (1996) determined that the more attached a person was to a destination, the less likely they would be fascinated with death, resulting in the tourists not viewing the dark tourism destination as being "dark". This thought process may be a possibility of explanation for why the relationships were negative between unique learning experience and the TPB constructs, resulting in both Hypothesis 5 and 6 not being supported. Farmaki (2013) strengthens this argument by determining that many tourists visit museums for the purpose of education, but museums will incorporate the concept of death to enhance the tourist experience.

Results from this study also indicate that participants of this study were not traveling to dark tourism destinations for educational purposes. Additionally, results indicate that individuals who were perhaps traveling for the purposes of unique learning experience had negative feelings or experiences with subjective norms, lending to the belief that their family and friends were not supportive of their choice to visit a dark tourism destination.

Raine (2013) discovered a group of tourists she classified as sightseers and passive recreationalists. These tourists can be themed as "incidental" as they were likely not seeking a dark tourism destination related to death and burials, but instead were looking for a destination to escape from everyday life. These statements can easily be supported by this research study as Hypotheses 7 and 8 were both positively supported in relationship to casual interest and attitudes (H7) and subjective norm (H8). The questions asked in this study specifically relate to value of tours, special promotions, and enjoying time with friends and family.

Individuals were seeking attitudinal experiences through their visits to dark tourism destinations, supporting Hypothesis 9. Unlike the results from Lam and Hsu (2004), subjective norms do play a role in behavioral intentions. This study found that the influence of societal norms and pressures do influence tourists' intention to visit dark tourism destinations, lending to Hypothesis 10 not being supported as expected. Regarding perceived behavioral control, when tourists feel capable and in control of their tourism choices, it will positively impact their behavioral intention or likelihood of visiting a dark tourism destination, supporting Hypothesis 11.

\section{Practical implications}

Practitioners working in tourism industries and communities of dark tourism destinations can greatly benefit from the results of this study. Managers of dark tourism destinations must realize that visitors are attracted to these locations for many different reasons (Bissell, 2009) and not just for fascination of death or paranormal activity. While this research does not focus specifically on individual motivating factors that influence behavior to visit, overarching attributes were determined to influence behavioral intentions more than others. The significant positive relationships found in this study between dark experience, unique learning experience, and casual interest suggest dark tourism destination managers offer a 
variety of tours and services to visitors and should be sensitive in how they display or present information so it does not come across as being offensive to tourists in the event they have strong emotional ties to the destination or individual(s) who may have been a victim at the destination.

Due to the broad nature of this study and its data collection efforts, the dark tourism locations visited by participants varied greatly. It can be concluded from the data that the use of television and contemporary media featuring dark tourism locations does positively influence tourists' behavioral intention to visit. Variables related to dark tourism destinations featured on television shows were more strongly favored in relationship to the dark experience construct than engaging entertainment. This indicates that tourists are curious about what they have seen on television or mass media and want to experience similar. Managers of dark tourism destinations featured on television shows should effectively market their locations as such to increase interest and tourism traffic to their destination. If paranormal tours are not currently being offered this would be a recommendation (if applicable) to generate more tourism interest.

Additionally, due to the increased popularity and reliance on websites and social media platforms for information, practitioners should register their location on dark tourism websites and registries so more curious travelers can easily locate them. Utilizing TripAdvisor.com and other similar travel websites is another option for practitioners to generate tourism interest to their destination. Making information readily available and easy to locate for tourists will continue to strengthen the relationship between perceived behavioral control and behavioral intention. Additionally, considering societal norms had a positive relationship with dark tourism constructs within this study, practitioners could market their destination as being taboo to tourists wanting to satisfy their rebellious curiosity.

\section{Limitations and future research}

This study has several limitations. Since the data was collected using Qualtrics Panels, potential participants are asked to self-report and assess whether they are eligible dark tourists for this study, based on given definition of dark tourism. Such self-assessment may not always be precise. If adopting this survey method, future research may consider asking participations to provide the specific dark tourism destination type that they have visited in the past 24 months, to help further confirm their eligibility for study participation. It is also recommended that if time and resources permit, future research consider collecting data onsite at dark tourism destinations. Also, this research study did not take into consideration the type of dark tourism destination visited by the respondents. Dark tourism destinations vary in the levels of violence and death that are associated with them (Seaton, 1996; Stone, 2006). Future research can investigate additional motivational factors of tourists to visit dark tourism destinations with varying levels of darkness associated to them.

Most of the previous studies are case studies with historical battlefields and concentration camps being the hot spot for tourist activity. It is important and yet lacking to explore the general pattern of the association between motivations and visit intentions to dark tourism sites in general. Ryan and Kohli (2006) suggested there are differences between dark tourism destinations created by natural disasters (e.g., earthquakes in Sichuan, China; Biran et al., 2014) and those that were sites of death at the hand of man (e.g., Auschwitz concentration camp). Moreover, Zhang et al. (2016) were among the few that explored the associated between motivation and association, but only on college students at one specific site. Although this study is inclusive of different dark tourist groups and dark tourism sites, future research may consider factoring in such difference in dark tourism destinations while exploring dark tourist motivations and visit intensions. 
IHR

36,1

\section{Conclusions}

This study serves as exploratory research examining the association between tourist motivations and visit intentions and paves the way for future research in dark tourism. This study contributes to the dark tourism literature by proposing a new theoretical framework linking and extending dark tourism motivation construct with the Planned Behavior Construct. Study results can also benefit practitioners in dark tourism sector.

\section{References}

Ajzen, I. (1991), "The theory of planned behavior", Organizational Behavior and Human Decision Processes, Vol. 50, pp. 179-211.

Ajzen, I. and Driver, B.L. (1992), "Application of the theory of planned behavior to leisure choice", Journal of Leisure Research, Vol. 24 No. 3, pp. 207-224.

Alegre, J. and Cladera, M. (2009), "Analysing the effect of satisfaction and previous visits on tourist intentions to return”, European Journal of Marketing, Vol. 43 Nos 5-6, pp. 670-685, doi: 10.1108/ 03090560910946990.

Armitage, C.J. and Conner, M. (2001), "Efficacy of the theory of planned behaviour: a meta-analytic review", British Journal of Social Psychology, Vol. 40, pp. 471-499.

Baloglu, S. (2000), "A path analytic model of visitation intention involving information sources, sociopsychological motivations, and destination image", Journal of Travel and Tourism Marketing, Vol. 8 No. 3, pp. 81-90, doi: 10.1300/j073v08n03_05.

Biran, A., Poria, Y. and Oren, G. (2011), "Sought experiences at dark heritage sites", Annals of Tourism Research, Vol. 38, pp. 820-841, doi: 10.1016/j.annals.2010.12.001.

Biran, A., Liu, W., Li, G. and Eichhorn, V. (2014), "Consuming post-disaster destinations: the case of Sichuan, China", Annals of Tourism Research, Vol. 47, pp. 1-17.

Bissell, L.J. (2009), Understanding Motivation and Perception at Two Dark Tourism Attractions in Winnipeg, $M B$, Thesis, University of Manitoba, Print.

Blom, T. (2000), "Morbid tourism: a postmodern market niche with an example from Althorp", NorskGeografisk Tidsskrift-Norwegian Journal of Geography, Vol. 54 No. 1, pp. 29-36.

Bowman, M. and Pezzullo, P. (2009), "What's so 'dark' about dark tourism?: death, tours, and performance”, Tourist Studies, Vol. 9 No. 3, pp. 187-202.

Byrne, B.M. (1998), Structural Equation Modeling with LISREL, PRELIS, and SIMPLIS: Basic Concepts, Applications, and Programming, Lawrence Erlbaum, Mahwah, NJ.

Cheng, S., Lam, T. and Hsu, C. (2006), "Negative word-of-mouth communication intention: an application of the theory of planned behavior", Journal of Hospitality and Tourism Research, Vol. 30 No. 1, pp. 95-116.

Conner, M. and Abraham, C. (2001), "Conscientiousness and the theory of planned behavior: toward a more complete model of the antecedents of intentions and behavior", Personality and Social Psychology Bulletin, Vol. 27 No. 11, pp. 1547-1561, doi: 10.1177/01461672012711014.

Crompton, J.L. (1979), “Motivations for pleasure vacation”, Annals of Tourism Research, Vol. 6 No. 4, pp. $408-424$.

Dale, C. and Robinson, N. (2011), "Research themes for tourism”, Dark Tourism, CABI, pp. 205-2017.

Farmaki, A. (2013), "Dark tourism revisited: a supply/demand conceptualisation", International Journal of Culture, Tourism and Hospitality Research, Vol. 7 No. 3, pp. 281-292.

Fishbein, M. and Ajzen, I. (1975), Belief, Attitude, Intention, and Behavior: An Introduction to Theory and Research, Addison-Wesley, Reading, MA.

Foley, M. and Lennon, J. (1996), "JFK and dark tourism: a fascination with assassination", International Journal of Heritage Studies, Vol. 2 No. 4, pp. 198-211. 
Hair, J.F., Black, W.C., Babin, B.J. and Anderson, R.E. (2010), Multivariate Data Analysis, 7th ed., Prentice Hall, Upper Saddle River, NJ.

Han, H. and Kim, Y. (2010), "An investigation of green hotel customers' decision formation: developing an extended model of the theory of planned behavior", International Journal of Hospitality Management, Vol. 29, pp. 659-668.

Han, H., Hsu, L. and Sheu, C. (2010), "Application of the Theory of Planned Behavior to green hotel choice: testing the effect of environmental friendly activities", Tourism Management, Vol. 31, pp. 325-334.

Hu, L. and Bentler, P.M. (1999), "Cutoff criteria for fit indexes in covariance structure analysis conventional criteria versus new alternatives", Structural Equation Modeling, Vol. 6, pp. 1-55.

Isaac, R.K. and Çakmak, E. (2014), "Understanding visitor's motivation at sites of death and disaster: the case of former transit camp Westerbork, The Netherlands", Current Issues in Tourism, Vol. 17 No. 2, pp. 164-179, doi: 10.1080/13683500.2013.776021.

Kamber, M., Karafotias, T. and Tsitoura, T. (2016), "Dark heritage tourism and the Sarajevo siege", Journal of Tourism and Cultural Change, Vol. 14 No. 3, pp. 255-269, doi: 10.1080/14766825.2016. 1169346.

Kline, R.B. (2005), Principles and Practice of Structural Equation Modeling, 2nd ed., Guilford Publications.

Kim, Y.H., Kim, M. and Goh, B.K. (2011), "An examination of food tourist's behavior: using the modified theory of reasoned action", Tourism Management, Vol. 32, pp. 1159-1165.

Konu, H. and Laukkanen, T. (2010), "Predictors of tourists' wellbeing holiday intentions in Finland", Journal of Hospitality and Tourism Management, Vol. 17 No. 1, pp. 144-149, doi: 10.1375/JHTM. 17.1.144.

Lam, T. and Hsu, C. (2004), "Theory of planned behavior: potential travelers from China”, Journal of Hospitality and Tourism Research, Vol. 28 No. 4, pp. 463-482.

Lam, T. and Hsu, C. (2006), "Predicting behavioral intention of choosing a travel destination", Tourism Management, Vol. 27, pp. 589-599.

Le, D.T. and Pearce, D.G. (2011), "Segmenting visitors to battlefield sites: international visitors to the former demilitarized zone in Vietnam", Journal of Travel and Tourism Marketing, Vol. 28 No. 4, pp. 451-463, doi: 10.1080/10548408.2011.571583.

Lennon, J. and Foley, M. (1999), "Interpretation of the unimaginable: the U.S. Holocaust Memorial Museum, Washington, D.C. and 'dark tourism"', Journal of Travel Research, Vol. 38, pp. $46-50$.

Lennon, J. and Foley, M. (2000), Dark Tourism: The Attraction of Death and Disaster, Cengage Learning EMEA, Andover, Hampshire.

Light, D. (2017), "Progress in dark tourism and thanatourism research: an uneasy relationship with heritage tourism”, Tourism Management, Vol. 61, pp. 275-301, doi: 10.1016/j.tourman.2017. 01.011.

Little, T.D., Cunningham, W.A. and Shahar, G. (2002), "To parcel or not to parcel: exploring the question, weighing the merits", Structural Equation Modeling, Vol. 9 No. 2, pp. 151-173.

Martini, A. and Buda, D.M. (2018), "Dark tourism and affect: framing places of death and disaster", Current Issues in Tourism, Vol. 23 No. 6, pp. 679-692, doi: 10.1080/13683500.2018. 1518972.

Miles, W. (2002), "Auschwitz: museum interpretation and darker tourism”, Annals of Tourism Research, Vol. 29 No. 4, pp. 1175-1178.

Miller, D. and Gonzalez, C. (2013), "When death is the destination: the business of death-tourismdespite legal and social implications", International Journal of Culture, Tourism and Hospitality Research, Vol. 7 No. 3, pp. 293-306.
Dark tourism: motivations and intentions 
IHR

36,1

Molle, A. and Bader, C. (2014), "Paranormal science from America to Italy: a case of cultural homogenisation", The Ashgate Research Companion to Paranormal Cultures, Ashgate, London, pp. 121-138.

Mowatt, R.A. and Chancellor, C.H. (2011), "Visiting death and life", Annals of Tourism Research, Vol. 38 No. 4, pp. 1410-1434, doi: 10.1016/j.annals.2011.03.012.

Peterson, R.A. (1994), “A meta-analysis of Cronbach's coefficient alpha”, Journal of Consumer Research, Vol. 21 No. 2, pp. 381-391.

Poria, Y., Butler, R. and Airey, D. (2004), "Links between tourists, heritage, and reasons for visiting heritage sites", Journal of Travel Research, Vol. 43, pp. 19-28.

Poria, Y., Reichel, A. and Biran, A. (2006), "Heritage site perceptions and motivations to visit", Journal of Travel Research, Vol. 44, pp. 318-326.

Powell, R., Kennell, J. and Barton, C. (2018), "Dark cities: a dark tourism index for Europe's tourism cities, based on the analysis of DMO websites", International Journal of Tourism Cities, Vol. 4 No. 1, pp. 4-21, doi: 10.1108/ijtc-09-2017-0046.

Raine, R. (2013), “A dark tourist spectrum”, International Journal of Culture, Tourism and Hospitality Research, Vol. 7 No. 3, pp. 242-256.

Robb, E.M. (2009), "Violence and recreation: vacationing in the realm of dark tourism", Anthropology and Humanism, Vol. 34 No. 1, pp. 51-60.

Rojek, C. (1993), Ways of Escape: Modern Transformations in Leisure and Travel, Palgrave Macmillan.

Ryan, C. and Kohli, R. (2006), “The Buried Village, New Zealand: an example of dark tourism?”, Asia Pacific Journal of Tourism Research, Vol. 11 No. 3, pp. 211-226.

Seaton, A. (1996), "Guided by the dark: from thanatopsis to thanatourism", International Journal of Heritage Studies, Vol. 2 No. 4, pp. 234-244.

Seaton, A. and Lennon, J.J. (2004), "Thanatourism in the early 21st century: moral panics, ulterior motives and ulterior desires", in Singh, T. (Ed.), New Horizons in Tourism: Strange Experiences and Stranger Practices, CABI Publishing, Cambridge, MA, pp. 63-82.

Sharpley, R. (2005), "Travels to the edge of darkness: towards a typology of 'dark tourism”, in Aicken, M., Page, S. and Ryan, C. (Eds), Taking Tourism to the Limits: Issues, Concepts, and Managerial Perspectives, Elsevier, pp. 215-226.

Sharpley, R. and Stone, P. (2009), The Darker Side of Travel: The Theory and Practice of Dark Tourism, Channel View Publications, Bristol.

Stone, P.R. (2006), "A Dark Tourism Spectrum: towards a typology of death and macabre related tourist sites, attractions and exhibitions", Tourism: An Interdisciplinary International Journal, Vol. 54 No. 2, pp. 145-160.

Strange, C. and Kempa, M. (2003), "Shades of dark tourism: alcatraz and robben island", Annals of Tourism Research, Vol. 30 No. 2, pp. 386-405.

Swan, J. (1981), "Disconfirmation of expectations and satisfaction with a retail service", Journal of Retailing, Vol. 57 No. 3, pp. 49-66.

Vazquez, D. and Xu, X. (2009), "Investigating linkages between online purchase behaviour variables", International Journal of Retail and Distribution Management, Vol. 37 No. 5, pp. 408-419, doi: 10. 1108/09590550910954900.

Yan, B., Zhang, J., Zhang, H., Lu, S. and Guo, Y. (2016), "Investigating the motivation-experience relationship in a dark tourism space: a case study of the Beichuan earthquake relics, China", Tourism Management, Vol. 53, pp. 108-121, doi: 10.1016/j.tourman.2015.09.014.

Yankholmes, A. and McKercher, B. (2015), "Understanding visitors to slavery heritage sites in Ghana”, Tourism Management, Vol. 51, pp. 22-32, doi: 10.1016/j.tourman.2015.04.003. 
Yoon, Y. and Uysal, M. (2005), "An examination of the effects of motivation and satisfaction on destination loyalty: a structural model”, Tourism Management, Vol. 26 No. 1, pp. 45-56, doi: 10. 1016/j.tourman.2003.08.016.

Zhang, H., Yang, Y., Zheng, C. and Zhang, J. (2016), “Too dark to revisit? The role of past experiences and intrapersonal constraints", Tourism Management, Vol. 54, pp. 452-464, doi: 10.1016/j. tourman.2016.01.002.

\section{Further reading}

Krisjanous, J. (2016), "An exploratory multimodal discourse analysis of dark tourism websites: communicating issues around contested sites", Journal of Destination Marketing and Management, Vol. 5 No. 4, pp. 341-350, doi: 10.1016/j.jdmm.2016.07.005.

Lennon, J. (2005), “Journeys in understanding what is dark tourism?”, The Sunday Observer, Vol. 23 October, available at: http://www.guardian.co.uk/travel/2005/oct/23/darktourism. observerscapesection.

\section{Corresponding author}

Heather Lewis can be contacted at: hrlewis@troy.edu

For instructions on how to order reprints of this article, please visit our website:

www.emeraldgrouppublishing.com/licensing/reprints.htm

Or contact us for further details: permissions@emeraldinsight.com 